\title{
The Implementation of CSR on EFL Students' Reading Class in Different Group Sizes
}

\author{
Ita Moraliawati ${ }^{1}$, Johannes Ananto Prayogo ${ }^{2}$, Gunadi Harry Sulistyo ${ }^{2}$ \\ ${ }^{1}$ SMAN Model Terpadu Bojonegoro \\ ${ }^{2}$ Pendidikan Bahasa Inggris-Universitas Negeri Malang
}

\begin{tabular}{l} 
INFO ARTIKEL \\
\hline Riwayat Artikel: \\
Diterima: 29-01-2019 \\
Disetujui: 17-10-2020 \\
Kata kunci: \\
reading comprehension; \\
collaborative strategic reading; \\
group arrangement sizes; \\
pemahaman membaca; \\
pembacaan strategis kolaboratif; \\
pengaturan grup
\end{tabular}

Alamat Korespondensi:

Ita Moraliawati

Pendidikan Bahasa Inggris

SMAN Model Terpadu Bojonegoro

J1. Raya Sukowati No. 00 Kec. Kapas Kab. Bojonegoro Jawa Timur

E-mail: ita.moralia@gmail.com

Reading is viewed as a form of communication. Sulistyo (2011) states that reading output must be able to reflect the success of negotiating meaning and messages intended by the writer to the readers. It means that comprehending the text that they read is one of the requirements that the readers need to achieve in order to make the writers' intention succesfully get through the readers. Reading comprehension skills help the readers to acquire proficiency in reading, effective learning and ability to conceptualize of written texts. In language teaching, reading is viewed as one of the four important skills that the students need to master. Reading activities integrate and combine many language skills. Reading skills also affects the other English skills a great deal. Some findings found that writing, speaking, vocabulary, and grammar can be taught through reading (Harmer, 2007). Moreover, Renandya (2017) stated that reading lots of books in English will help the students master the language. Reading surely becomes one of the skills that the students need to master well in order to have good profeciency in English.

In spite of the importance of reading, some previous studies found that reading has become the most difficult skill that the students need to master. A preliminary study conducted by Elfiondri, Kasim, Mustafa \&, Putra (2017) in Syiah Kuala University found that the skill the students experience most difficulty is reading. Some other researchers in Indonesia (Gani, Yusuf, \& Susiani, 2016) and Saudi Arabia (Alamin \& Ahmed, 2013) find the same phenomena in students' English skill. Furthermore, a study conducted by (Sulistyo, 2013) has shown that first year students at university level in Malang are not ready yet for academic reading. This might be traced back from the students reading achievement in their Senior High Schools. Kompas (2018) wrote that the result of English National examination in 2018 for senior high school students were not satisfying. More than 80 percent of the students get below 55. This result is still considered to be low and not being able to cope with the necessity to access the academic reading in the university level. In addition, a survey initiated by OECD which stands for Organization for Economic Cooperation and Development (2013) with the purpose to evaluate the education system from 72 countries in the world in 2012 resulted that Indonesia was on the $64^{\text {th }}$ rank among the other countries as the participants of PISA (Program for International Students Assesment). This survey was conducted on the students in high school levels. The rank of Indonesia in the bottom two in most literate nations in the world as the result of the survey conducted by OECD (2013) showed that the reading comprehension competence of Indonesia people is still in poor level. 
In contrast to the facts, Clark \& Akerman (2006) stated that the competence in reading has significant effect in students' life since it can be an access to social, economic and civic life. Reading competence is also considered as an underlying means of supporting the success of learning process (Ivey \& Broaddus, 2001). It also has positive influences on academic performance (Adetunji \& Oladeji, 2007). Academic success, personal independence, and secure employment depend on the fundmental skill of reading (Calhoon, 2005). Thus, the urgency in improving the students' reading comprehension competence is real and the students are required to have good ability in reading comprehension.

Looking back at the phenomena on the students' difficulty in reading, the effectivity of the conventional teaching reading class might be questioned. The conventional reading class used recently focuses on the ability of the students to read texts and then answer some questions related to the text. The students are conducted to read the text by several steps in observing, questioning, exploring, associating, and communicating. In the process of reading activity, the students are given chance to discuss the text with their friends. But, this strategy seems to be more accomodating on all skills rather than only focusing on reading itself. Therefore, it is important for the teachers to find the effective reading strategy that can boost the students' reading comprehension skill particularly.

Grabe, (2009) defines strategy as processes that are consiously controlled by readers to solve reading problems. There are some benefits in applying strategic reading. Aside from building efficiency in strategic processing, strategic readers know when, how and why to use strategies effectively and recognize appropriate contexts for using effective strategies. Strategic readings also makes the students involve more actively in reading, read far more extensively, and have more endurance in reading. Strategic readings also enable the students to find out the information relevant to their need and interest and build efficiency and automaticity in strategy use for routine situations that they usually meet (Grabe, 2009). That's why, preparing the students to be a strategic readers might be needed. The quest on a more effective strategy in reading is prominent to be carried out. Experts have provided many strategies in language learning to help the teachers improve their students' English proficiency ranging from memory strategies to social strategies (Zhou, 2010).

Collaborative Strategic Reading (CSR) is viewed as one alternative strategy that can be implemented in reading activity. This study proposed to have CSR to be applied in the classroom in order to increase the students' reading comprehension skill. CSR is a peer-mediated reading comprehension instructional model informed by the methods in reciprocal teaching (Palincsar \& Brown, 1984), cooperative learning (Johnson, Johnson, \& Stanne, 2000), and transactional strategies instruction (Pressley, El-Dinary, Gaskins, Schuder, Bergman, Almasi, \& Brown, 1992). According to (J. K. Klingner \& Vaughn, 2000), the steps in CSR starts with previewing, of which purpose is to motivate the students' interest in what they are reading to activate the background knowledge, and to assist the students in generating prediction about the text to be read. In previewing, the students do brainstorming what they have already know about the topic and predicting the things that will be learnt from the text. Next, Click and clunk allows the students to monitor what they are reading and to think the information they want to know more about or causing them difficulties. The third strategy, get the gist, enable the students to know how to determine the main idea of a passage. The last strategy in CSR, the wrap up strategy, gives the students an opportunity to review what they have read to assist with understanding and remembering what they have learnt. The strategies in CSR are designed to teach students with diverse abilities comprehension strategies for use with expository text (Klingner, Vaughn, \& Boardman, 2015). CSR explicitly uses strategy instructions consisting of four strategies in CSR to teach meta-cognitive and self-monitoring skills theorized to lead to improved reading comprehension (Klinger, Vaughn, \& Schumm, 1998). Klinger et al (2015) stated that the approach uses a mix of whole class instruction and small cooperative group peer learning groups. Whole group instruction in CSR begins with teacher modelling, role playing, and teacher think-alouds. These steps are followed by the formation of heterogeneous cooperative learning groups in which students employ four comprehension strategies before, during and after reading: preview, click and clunk, get the gist, and wrap up (Kim, Clapper, Vaughn, \& Bremer, 2002).

There are some reasons for implementing CSR to boost the EFL students' reading comprehension skill. Previewing and prediciting (preview), monitoring for understanding and vocabulary knowledge (Click and Clunk), main idea (Get the Gist) and self-questioning and passage understanding (Wrap-up) are the four reading comprehension strategies taught in Collaborative Strategic Reading (J. K. Klingner \& Vaughn, 2000). The four reading strategies have been demonstrated to be effective in enhancing students' understanding of text, as well as in improving skills at reading for meaning for a range of learning types, including students with learning disabilities, low achievers and students who are not native English speakers (J. K. Klingner \& Vaughn, 1999). Furthermore, these strategies have been effective with a range of grade levels including elementary, middle, and high school students (Rosenshine \& Meister, 1995).

Most of the studies conducted in CSR investigated the effect of CSR on students' reading comprehension skill. Several studies using CSR was conducted to the students with diverse learning needs in general education classroom. The finding of a study conducted by (J. Klingner, Vaughn, Dimino, Schumm, \& Bryant, 2001) showed that CSR was effective in improving both understanding text and learning content. Another study on CSR was conducted to the middle school students. (Vaughn et al., 2011) conducted an experimental study to investigate the effects of CSR and metacognitive strategic learning on the middle school students' reading comprehension skill in Texas Colorado. This study resulted on the finding that there is a significant 
difference on the result of students' Gates-MacGinitie reading comprehension test result. The result of this study was then strengthened with a replication study on different subjects. The result indicated that CSR was effective with struggling readers. In Asian and European context, studies of CSR (Karabuga \& Kaya, 2013; Khonamri \& Karimabadi, 2015) as well as in Indonesia context (Amrina, 2016; Nohenriady, 2011) were conducted with linear results.

It was obvious from the previous studies described previously that CSR has positive impacts in EFL and ESL reading skill although some other variables might not be affected by the implementation of CSR in class. However, there are some gaps to justify the need of this study to explore more studies on CSR implementation. The first gap is that most of the previous studies in CSR were conducted in American and Asian contexts. The implementation of CSR in American context were mainly targetted for the students with dissabilities and elementary students. Whereas, the implementation of CSR in Asian \& European context were mainly intended for the EFL students in the university level. The effectiveness of CSR for senior high school students have not been investigated yet. Secondly, there were only few studies of CSR implementation in the local context. Moreover, a variable such as different learning styles was revealed to give no significant effects for the students' reading comprehension in CSR implementation. Thus, a study to relate CSR and another variable in teaching reading is worth to be analized further.

According to Gani, Yusuf \& Susiani (2016), CSR is a combination of reading comprehension strategy instruction and cooperative learning. In CSR, students read and discuss text through a combination of teacher-led activities and student-led cooperative group work. Since the implementation of CSR deals a lot with group arragement, finding the adequate arrangement of the groups should also be a concern. Fisher and Ellis (1990) emphasize that most of the definitions of a group indicate the sharing element among members as the key factor which defines the existence of a group. The structure of a group can influence the level and success of interaction in a group. Small group work (also known as cooperative or collaborative learning or peer learning) involves a high degree of interaction. The effectiveness of learning groups is determined by the extent to which the interaction enables members to clarify their own understanding, build upon each other's contributions, sift out meanings, ask and answer questions. Davis (1993) states that group work involves students working collaboratively on set tasks, in or out of the classroom. Group works vary from pairs, small groups to large group of students depending on the activity they have to do and their roles inside the groups. Using a variety of grouping technique is important to allow the learners to practice different types of things. Pairs are usually assigned for the activity where each student needs partners like in dialogue, games, or completing taskwork. While larger groups may be assigned in role plays, races, games which need more players, or discussion. The size chosen will depend on the number of students, the size of the classroom, the variety of voices needed within a group, and the task assigned. Groups of four-five tend to balance the needs for diversity, productivity, active participation, and cohesion. The less skilful the group members, the smaller the groups should be (Davis, 1993).

There are some reasons on why the group arrangement sizes that is investigated in this study is pairs and small groups. Firstly, group size is assumed to be one of the factor affecting the students' learning outcomes (Vaughn, Klingner \& Bryant, 2001). Yet, so far, there were very few studies investigating the relationship between the group sizes and the learning outcomes. Some studies found that there is a relationship between the group sizes arangement and the students' learning outcomes in various English skills. A study conducted by Lasito \& Storch (2013) investigating the comparison between pairs and small groups interaction on oral test showed that pairs arrangement made the students produce more language than small groups did. Moreover, in a recent meta-analysis of the extent to which variation in effect sizes for reading outcomes for students with disabilities was associated with grouping format for reading instruction, small groups were found to yield the highest effect sizes (Elbaum, Vaughn, Hughes, Moody, \& Schumm, 2000). This research supports the eficacy of small group instruction and shows that there is a form of relationship between the group sizes and the learning outcome. It was also stated that the overall number of small-group studies available in the sample was two. Other reasearch conducted by Elbaum, Vaughn, Hughes \& Moody (1999) suggested that pairs yielded the most effect for the students' learning outcomes among several group sizes (students' pairs, small groups, and combination of different formats) that has been set.

On the other hand, some research found different results. Wilkinson \& Fung (2002) stated that there seems to be some form of negative relationship, either linear or non-linear, between the number of the students in a group and the learning outcomes. Furthermore, a study conducted by Mayo \& Zeitler (2017) indicated that there was no significant difference between performances of pairs and groups. The difference result of the studies might be caused by many factors. In the previous studies, the different group sizes arrangement affects the students learning outcomes in speaking of senior high scool students and reading for the elementary students as it was found in Lasito \& Storch (2013). For the students with dissabilites as it was investigated by Elbaum et al (1999) and Elbaum et al (2000), the smaller group size was proven to gain positive effects than the bigger group sizes for the students reading comprehension. Yet, some other previous studies did not find the significant difference of the students learning outcomes in writing and vocabulary learning set in different group sizes as it was found in Wilkinson \& Fung (2002) and Mayo \& Zeitler (2017). Thus, the effect of group sizes to senior high school students' learning outcomes need to be further investigated. 
This research is interested to relate the use of CSR in students' reading comprehension class and the group arrangement sizes assigned to them. Since there were limited studies about CSR in the local context, and there has not been any studies investigating the effect of different group arrangement in the implementation of CSR in reading class, the investigation on which group arrangement size, small groups of four or pairs, is more effective in implementing CSR in class is needed be put into a concern and is worth conducting. In short, this study is aimed to investigate the effectiveness of CSR on EFL students' reading comprehension and relate the implementation of CSR with different group size arrangement, particularly small group of four and the smaller size (pairs) to the students' reading comprehension. This study is conducted in Indonesia context with the targetted subject the students of senior high school. CSR is chosen as the strategy as it is expected to boost the students reading comprehension with the four strategies applied in the implementation. The relationship of CSR and group size arrangements is investigated to see whether difference group size gains different result of the students' reading comprehension. Thus, an experimental study is conducted to see the effects of CSR to the students' reading comprehension accross difference group arrangement sizes.

\section{METHODS}

This study employs an experimental design, which is used in a study of the effect of the systemic manipulation of one variable(s) on another variable (Ary, Jacobs, \& Sorensen, 2010). This design was chosen because the study was intended to investigate the effects of CSR on students' reading comprehension in the high school level and the effects of different group sizes assigned to the subjects during the treatment. A quasi-experimental designed was employed since it is not possible to randomly assign subjects to treatment groups. This study used the simplest factorial design (2x2) involving four cells as presented in the table below. The first one, $\mathrm{A}_{1} \mathrm{~B}_{1}$ showed the students who were taught using CSR assigned in pairs grouping; $A_{1} B_{2}$ showed the students receiving a reading instruction by using CSR assigned in small grouping; $A_{2} B_{1}$ represented the students who recieved the conventional teaching reading strategy assigned in pairs, and $\mathrm{A}_{2} \mathrm{~B}_{2}$ represented the students in the control group who were taught using conventional teaching reading strategy assigned in groups of four.

Table 1. The Quasi-experimental Design of this Study

\begin{tabular}{|c|c|c|c|c|}
\hline \multicolumn{2}{|c|}{ Independent Variables } & \multicolumn{2}{|c|}{$\begin{array}{c}\text { (A) } \\
\text { Teaching Strategy }\end{array}$} & \multirow[t]{2}{*}{ Total } \\
\hline & & $\begin{array}{l}\text { CSR } \\
\left(\mathrm{A}_{1}\right)\end{array}$ & $\begin{array}{l}\text { Conventional } \\
\text { (A2) }\end{array}$ & \\
\hline (B) & Pairs & $\mathrm{A}_{1} \mathrm{~B}_{1}$ & $\mathrm{~A}_{2} \mathrm{~B}_{1}$ & $\mathrm{~B}_{1}$ \\
\hline Group Arrangement Sizes & Small Groups of 4 & $\mathrm{~A}_{1} \mathrm{~B}_{2}$ & $\mathrm{~A}_{2} \mathrm{~B}_{2}$ & $\mathrm{~B}_{2}$ \\
\hline Total & & $\mathrm{A}_{1}$ & $\mathrm{~A}_{2}$ & \\
\hline
\end{tabular}

The target population of this study was the eleventh graders in Indonesian context which shared the same school curriculum. Yet, only the sampling accessible for the researcher, the eleventh graders of SMAN Model Terpadu Bojonegoro in 2018/2019 academic year, were involved in this study. Among the 6 classes available in SMAN Model Terpadu Bojonegoro, four classes from the science program were chosen since they have the most resemblance in characteristics. Two of the classes became the control groups while the rest two were assigned as the experimental groups. In the treatment process, the students in the experimental groups received CSR instruction for 8 meetings and those in the control groups got 8 meetings of reading instruction based on conventional teaching strategy which was frequently used by the teacher.

The implementation of CSR strategy in the experimental group was based on the CSR procedure promoted by Klingner, Vaughn, Dimino, Schumm \& Bryant (2001). There were two phases conducted in eight meetings. The first and second meetings were devoted to explicit instruction of CSR strategy. The next third up to eight meeting were used for collaborative application of CSR strategy. The treatment was conducted for eight meetings in an assumption that the students had never experienced using this strategy in reading class and they needed adequate time to grasp explicit instruction and do collaboration of CSR as well. All of the four strategies in CSR was practiced in each meeting with specific alotted time for the practice of each strategy. In the first and the second meeting, the students were scaffolded in the practice of each strategy in CSR. The next four meetings were devoted to practice the strategy of CSR where the teacher gradually limited her involvement in instructing the students, and instead, only monitor, gives assistance for the groups encountering problems and facilitated classroom interaction. The last two meetings focused on the students independent works without much interference from the teacher. In eight-meeting treatment, it was assumed that the students had already had adequate time to learn analytical, apply CSR and practice CSR while reading English texts. 
In this study, the main instrument utilized to collect the data was post-test on students' reading comprehension. This instrument will be the primary instrument to measure the students' reading comprehension skill after the treatment and to test the hypotheses of the study. The reading comprehension test that was utilized in this study is a 40-item reading tests. The number of the test items was chosen considering on the class duration which usually sets around 90 minutes. Mainly the items are taken from the national examination item test about analytical exposition with various topics. The construction of the test followed the procedure of test development by Sulistyo (2002). The major components of the designed test blueprint were adapted from Sulistyo (2017), namely the objective of the test, competence standard, basic competence, indicators, comprehension level, item number and the percentage of the test items. The next step, the test item construction which follow the standart form of test in senior high school's national examination stated in the assessment guidelines for teachers and schools issued by Direktorat Pembinaan SMA in 2017. The texts were selected to suit the students level employing FleshKincaid formula to test the readibility. The instruments were then validated and revised as the feedback given. Considering the ways to investigate the validity of the test, content validity is chosen to examine the validity of the test. The test specification and blueprint are provided to compare the content of the instruments to the objectives and materials learned. The test approach as well as the scoring used in this study was discrete point of objective test in the form of multiple choice test items with 5 options as it is performed in National Examination as the standard test for Senior High School students, based on the assessment guidelines for teachers and schools issued by Direktorat Pembinaan SMA in 2017.

Data analysis was aimed at testing the research hypothesis. In analyzing the data, this research used descriptive statistics presenting the data in the forms of graphic, measure of central tendency including mean, median and mode, and measures of variability which include range, variance and standard deviation. The data analized was obtained from the result of the reading comprehension post-test in the form of reading test scores. T-test was employed to test whether the first and the second hypothesis investigating on the effect of CSR and different group arrangement sizes on the students were accepted. Then, a two-way ANOVA was needed to test whether there was any interaction between the strategies used and the group arrangement sizes assigned to the students. In order to accept or reject the hypothesis, the criteria of acceptance or rejection of the null hypothesis were to be stated. The following criteria direct us to consider whether they hypothesis is accepted or not. The null hypotheses are accepted if the computed value of $\mathrm{F}$ is equal and less than the $5 \%$ level of significance that is .05. Thus, if it is found, on the basis of statistical test, that $p$ (sig.) $<0.05$, the null hypothesis is rejected and the alternative hypothesis is accepted.

\section{FINDINGS}

The brief description of the data categorized based on the strategy was presented in Table 2 below. The data was categorized based on the strategy used in the each class.

Table 2. Descriptive Data of Post-test Scores in the Experimental and the Control Groups

\begin{tabular}{|c|c|c|}
\hline \multicolumn{3}{|c|}{ Statistics } \\
\hline & $\operatorname{CSR}\left(\mathbf{A}_{1}\right)$ & CONVENTIONAL (A2) \\
\hline Valid & 58 & 57 \\
\hline Missing & 0 & 1 \\
\hline Mean & 42.0345 & 36.4737 \\
\hline Std. Error of Mean & 1.52474 & 1.71462 \\
\hline Median & 41.0000 & 35.0000 \\
\hline Mode & $32.00^{\mathrm{a}}$ & 25.00 \\
\hline Std. Deviation & 11.61210 & 12.94508 \\
\hline Variance & 134.841 & 167.575 \\
\hline Range & 47.00 & 53.00 \\
\hline Minimum & 20.00 & 17.00 \\
\hline Maximum & 67.00 & 70.00 \\
\hline Sum & 2438.00 & 2079.00 \\
\hline
\end{tabular}

a. Multiple modes exist. The smallest value is shown 
Table 2 provides descriptive statistics of the two data compared. The data was the post-test score of the students arranged according to te strategy implemented in each group. CSR $\left(\mathrm{A}_{1}\right)$ represented the data obtained from the post-test score of the students taught using CSR while Conventional $\left(\mathrm{A}_{2}\right)$ represented the data obtained from those taught using Conventional strategy. In Table 3.2, $\mathrm{N}$ in the first row represented the number of the data being described in each group. The number of data obtained from CSR group was 58 while in conventional strategy, the number of the data was 57.

The next row was the description of the mean value from each group. The mean is the average performance level of each group. Based on Table 2, the mean scores of control and experimental groups were 36.47 and 42.03 respectively. It means that the mean score of the students in CSR group was higher than those in conventional groups. There was just a slight difference in the mean score of the CSR group and conventional group. It may indicate that the students taught using CSR strategy achieved slightly better than the students taught using Conventional Strategy. Yet, to confirm it, the significance of the mean scores' difference still needed to be analysed further using t-test. Table 2 also showed the minimum and the maximum scores from each group. The minimum score of CSR Group was 20. Yet, conventional group marks the minimum score was 17. The maximum score for CSR group was 67 while in the conventional group was 70.

The data from pairs group was obtained from the two classes which were assigned to work in pairs either using CSR or Conventional Strategy. The same arrangement was carried out to the data from small group. The data taken from two classes assigned in small group of 4 using CSR and Conventional Strategy each were used as the data for the small group. From the descriptive statistics of the data obtained from both pairs and smaal goups of 4, it was found that there was barely no significant difference in the average (mean) of both groups. The mean of each group was about 39.28 and 39.27 respectively. The slight difference of the mean scores from both groups may indicate that there is no significant difference between pair groups and small group. Yet, this need to be analyzed further using the test to compare the data whether both group was significantly different.

There are some ways to check the distribution of the data. Leech et al (2005) stated that one of the properties indicating that the curve is normal or normally distributed can be seen from the mean, median and mode. When the mean, median and mode are equal, it means that the distribution of the data is relatively normal. This was supported with the skewness which marks .406 and .404 respectively, for pair group the former and for small groups for the latter. The skewness indicates the frequency distribution. If one tail of a frequency distribution is longer than the other, and if the mean and the median are different, the curve is skewed (Leech et al, 2005). Because most common inferential statistics assume that dependent variable is normally distributed, whether our variables are highly skewed to be noticed. Bulmer (1979) suggests some rules to interpret the skewness. If the value is less than -1 or greater than +1 , the distribution is highly skewed, in other word, it is not normally distributed. When it is between -1 and $-1 / 2$ or between $+1 / 2$ and +1 , the distribution is moderately skewed. Yet, if skewness if between $-1 / 2$ and $+1 / 2$, the distribution is approximately symetric. Table 3.3 showed that the skewness of the data for both pair and small group were .406 and .404 respectively. It means that the skewness is between $-1 / 2$ and $+1 / 2$. Thus, it can be stated that the data was normally distributed. The complete data description of the students scores' assigned in pair and small group of 4 is provided in Appendix 9. Yet, the histogram of the skewness of data is presented in Figure 1 and 2.

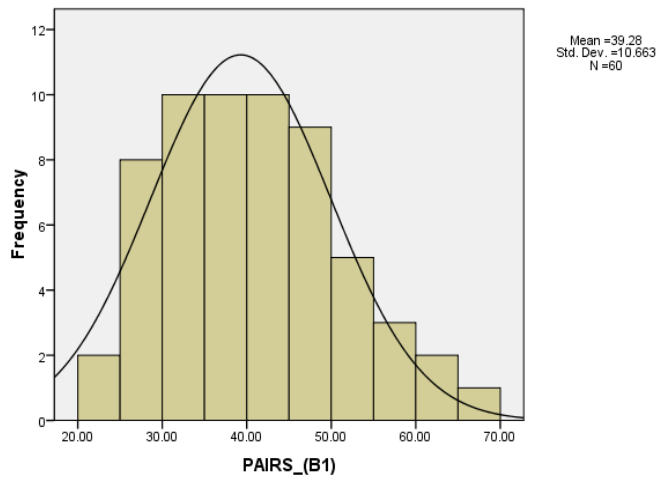

Figure 1. The Histogram of Students' Scored Assigned in Pairs 


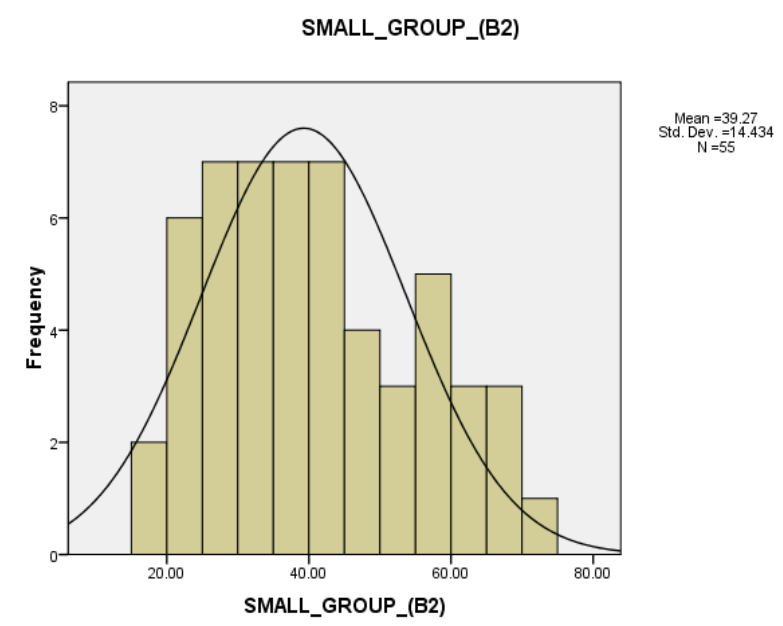

Figure 2. The Histogram of Students' Scored Assigned in Small Groups of 4

Every statistical test has assumptions. Assumptions may help the researcher to determine whether it is reasonable to perform a specific statistical test (Leech et al, 2005). If the statistical assumptions are not met, it may provide incaccurate result and may lead to the wrong conclusion. Homogeniety, normality and linearity are among the tests needed to be conducted to investigate whether the statistical assumptions were met. In this study, homogeneity and normality tests using SPSS 16 were performed to investigate whether the data fulfilled the statistical assumptions. The result of homogeneity and normality tests became the prerequisite basis in selecting parametric or non-parametric statistics tests for hypothesis testing. When it is found that the statistical assumptions are met, parametric tests such as t-test and ANOVA is likely to be employed to analyze the data.

Before the data was analysed to investigate whether the variables assigned in each group did have impact to the students' score by using t-test and two-way ANOVA, a homogeneity testing was conducted first. The statistical homogeneity testing was conducted by Levene's test in SPSS 16.0. The data obtained from each group was considered equal and homogenous if the observed significance value or $\rho$ value was greater than 0.05 significance value $(p$ value $>$ sig .05). The resut of homogeniety test for the data arranged baed on the strategy used showed the significant value $(p)$ of 0.520 , a little bit greater than 0.05. Thus, it was concluded that the data arranged based on the strategy used was homogenous. Meanwhile, the Levene's test on the data arranged by group sizes resulted 0.17 significant value, greater than 0.05 . This made the data arranged based on the group sizes was also homogenous. Since the statistical assumptions were met, parametric tests of t-test and two-way ANOVA were performed to test the hypotheses.

The first research question addressed on investigating whether the students taught using CSR achieved better reading scores than those taught using conventional teaching strategy. To answer this research question, the data was computed on the basis of the strategy used. The score of the students taught using CSR were compared to those taught using conventional strategy. Since the data had already fulfilled the homogeneity and normality test, the data was analysed using parametric statistics. Since there were only two data compared, the test employed in for this data was t-test. The result of data analysed by using t-test was presented in table 3.

Table 3. The Result of T-Test on CSR Group and Conventional Group

\begin{tabular}{|c|c|c|c|c|c|c|c|c|c|}
\hline & \multirow[t]{2}{*}{$\mathbf{F}$} & \multirow{2}{*}{ Sig. } & \multirow[t]{2}{*}{$\mathbf{t}$} & \multirow{2}{*}{ df } & \multirow{2}{*}{$\begin{array}{l}\text { Sig. }(2- \\
\text { tailed) }\end{array}$} & \multirow{2}{*}{$\begin{array}{c}\text { Mean } \\
\text { Difference }\end{array}$} & \multirow{2}{*}{$\begin{array}{l}\text { Std. Error } \\
\text { Difference }\end{array}$} & \multicolumn{2}{|c|}{$\begin{array}{l}\text { 95\% Confidence Interval of the } \\
\text { Difference }\end{array}$} \\
\hline & & & & & & & & Lower & Upper \\
\hline $\begin{array}{l}\text { Equal variances } \\
\text { assumed }\end{array}$ & .416 & .520 & 2.737 & 113 & .007 & -6.23140 & 2.27701 & -10.74257 & -1.72022 \\
\hline $\begin{array}{l}\text { Equal variances not } \\
\text { assumed }\end{array}$ & & & 2.740 & 111.397 & .007 & -6.23140 & 2.27427 & -10.73784 & -1.72495 \\
\hline
\end{tabular}


The result of T-Test presented in Table 3 revealed 0.007 significant value (2-tailed). The significant value was lower than 0.05 level of significance ( $p$ value $<$ sig .05). This indicated that the significant value of .007 was statistically significant. Thus, the null hypothesis stating that there was no significant difference in reading comprehension between the students taught using CSR and the students taught using conventional strategy was rejected and the Hi was accepted. Consequently, it can be implied that the students' reading comprehension score taught using CSR was significantly different than those taught using conventional strategy.

Similar to the analysis to answer the first research question, another T-test was conducted to answer the second research questions on investigating whether there was a significant difference of the students' reading comprehension scores between the students assigned in pairs and in small groups of 4 . The data used in this analysis was arranged on the basis of group sizes assigned to the students. To analyse the data, the scores of the students assigned in pairs were compared to those assigned in small groups. Analysis using parametric statistics was employed since the data had fulfil the statistical assumptions and revealed to be normally distributed and homogenous. Thus, t-test was used to analyse the data from both groups. The result of the t-Test was displayed in table 4.

Table 4. The Result of T-Test on Pairs and Small Groups of 4

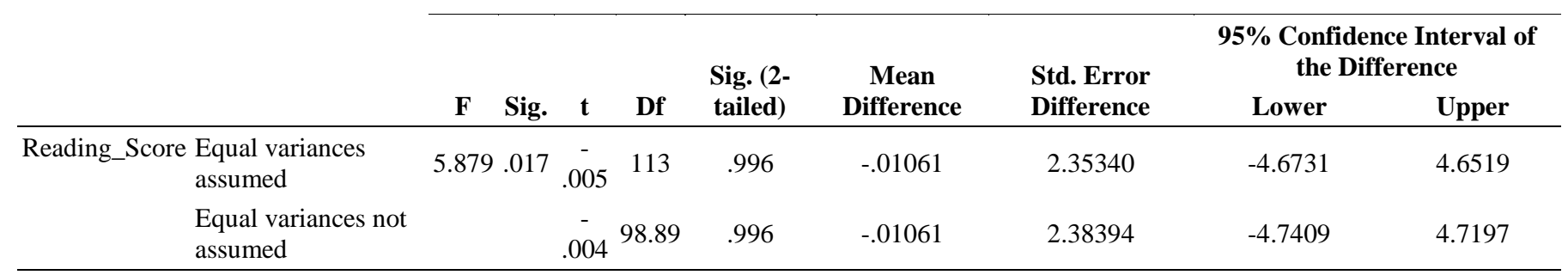

Table 4 showed the result of t-test conducted to the data on the basis of group sizes obtained 0.996 significant value. The significant value of 0.996 was greater than 0.05 level of significant. This indicated that the null hypothesis could not be rejected and the HI could not accepted. It means that there was no significant difference between the scores of the students assigned in pairs and those assigned in small groups of 4 in their reading classes.

The third research question was intended to investigate the interaction between the strategy used in reading class and the group sizes assigned. The result of normality and homogeneity test had shown that the data were distributed normally and homogenous, thus a parametric test was employed. To investigate the interaction among variables, ANOVA test was used. Since there were two independent variables employed in this study, a two-way ANOVA was used to analyse the data. The result of the two-way ANOVA test was presented in table 5.

Table 5. The Result of Interaction Analysis among the Teaching Strategies and Group Arrangement Sizes on Students'

Reading Comprehension

\begin{tabular}{|c|c|c|c|c|c|}
\hline Source & Type III Sum of Squares & df & Mean Square & $\mathbf{F}$ & Sig. \\
\hline Corrected Model & $1060.884^{\mathrm{a}}$ & 4 & 265.221 & 1.726 & .149 \\
\hline Intercept & 18628.405 & 1 & 18628.405 & 121.263 & .000 \\
\hline Strategy & 966.261 & 1 & 966.261 & 6.290 & .014 \\
\hline Group_Size & 169.806 & 2 & 84.903 & .553 & .577 \\
\hline Strategy $*$ Group_Size & 2.298 & 1 & 2.298 & .015 & .903 \\
\hline Error & 16898.211 & 110 & 153.620 & & \\
\hline Total & 195379.000 & 115 & & & \\
\hline Corrected Total & 17959.096 & 114 & & & \\
\hline
\end{tabular}

a.

$\mathrm{R}$ Squared $=, 059$ (Adjusted R Squared $=, 025)$

Table 5 showed that in strategy factor, the $\mathrm{F}$ observed was 6.290 with $p$ value $0.014<0.05$. It confirmed what had already been stated in the result of t-test that the null hypothesis stating that there was no significant difference between the students taught using CSR strategy and the students taught using conventional strategy was rejected and the HI was accepted. It means that the reading comprehension scores of the students taught using CSR was significantly different from those taught using conventional strategy. The result of two-way ANOVA test also gave information on the effect of group arrangement sizes. 
The F observed was 0.553 with $p$ value $0.577>0.05$. It means that the null hypothesis was accepted and the HI was rejected. It justified the result of the t-test on the data arranged on the basis of group size assigned that there was no significant difference of the students' reading comprehension scores between the students assigned in pairs and in small groups of four.

The analysis of interaction between the strategy and the group size resulted $\mathrm{F}$ observed 0.015 with $p$ value 0.903 . The significant value ( $p$ value) obtained from this analysis was 0.200 , greater than 0.05 level of significance. This made the null hypothesis stating that there is no interaction between the teaching strategy and the group arrangement sizes was accepted and the HI was rejected. In sum, it can be inferred that there was no interaction between the strategy used in teaching reading and the group arrangement sizes assigned to the students.

\section{DISCUSSIONS}

There are some theories and previous studies related to CSR and reading comprehension as stated in the background. A study conducted by Klingner Vaughn \& Schumm (1998), revealed that CSR provided positive support for students learning and students made significant improvements in different aspects of reading abilities. Previously, in 1996, Klingner, Vaughn \& Schumm conducted a study showing that 37 fifth-graders gain positive effects from the implementation of CSR. These students helped each other use strategies to support their comprehension. Similar result was revealed in their 1998 study conducted in the fourth graders. The experimental groups showed greater gains in reading comprehension and showed the same content knowledge aquisition as students who received traditional teacher-led instruction. In the studies conducted by Klingner, Vaughn, Arguelles, Hughes \& Leftwich (2004) and (Boardman et al., 2016) it was confirmed that CSR provided progressive support for students' learning and students. Furthermore, in relation to the use of strategic reading in reading class, Grabe (2009) states that CSR shows strong potential as an approach to combined-strategies instructions implemented for both L1 and L2 students.

The first test result revealed that the students taught using CSR performed better than those taught using the conventional strategy. The evidence was shown from the mean score of CSR group which marks 5.56 points higher than conventional strategy group. This result was justified further with the result of the first hypothesis testing using t-test which implied that the mean scores of the students taught using CSR was significantly different from those taught using the conventional strategy with the advantage in the side of CSR group. Therefore, CSR was confirmed to be a more effective strategy than the conventional strategy implemented in this study in boosting the students' reading comprehension on exposition texts. The finding of this study does not only support the existing theories of CSR, but it is consistent with several previous studies in CSR as well. The result of the study is in line with the theory by Vaughn et al (2011), stating that the students of middle school using CSR outperformed students in the comparison classes on a standardized reading comprehension measure. The finding of the study is notable since it indicates the positive impacts of CSR on older readers. This study reveals that CSR is effective to be implemented to the students in high school, particularly in expository texts. Previously, CSR was only proven to be effective for elementary and dissabilities students.

There are some reasons that justify the positive effects of CSR to reading comprehensions. Grabe (2009) states that in CSR, the students are forced to activate prior knowledge, construct word guesses, monitor comprehension difficulties, clarity information, restate important ideas, summarize the text, and form appropriate questions about the text. All of those activites provided in CSR help the students to gain more understanding on reading texts. This study implemented four strategies of CSR namely preview, click and clunk, get the gist, and wrap up. Those four strategies the ability of the students to activate prior knowledge, construct word guesses, monitor comprehension difficulties, clarity information, restate important ideas, summarize the text, and form appropriate questions about the text. The more the students implement the strategies of CSR, the more they get used to implement the strategies to new texts. Thus, the more reading understanding they may gain. This finding supports the theory by Karabuga \& Kaya (2013) that the four strategies applied in CSR had lead to gains in terms of students' achievement, participation, motivation.

Another reason is that the steps of CSR implemented in this study was designed carefully based on Klingner, Vaughn, Boardman, \& Swanson (2012) which arranged the procedure of CSR in 4 steps, preview, click \& clunk, get the gist and wrap up to achieve its goal. The four strategies in CSR leads the students to develop their reading skills. The use of strategy in reading is prominent to the result of reading itself. As Grabe (2009) states that strategic reading doesn't only build the efficiency in strategic processing. It makes the strategic readers know the appropriate time, reason and way to use strategies effectively and recognize appropriate contexts for using effective strategies. They also engage actively in reading, read far more extensively, and have the motivation to read for longer periods of time; they use reading to seek out information relevant to their needs and interests; they build efficiency and automaticity in strategy use for routine situations that they commonly encounter; and they have heightened levels of metacognitive and metalinguistics awareness that they can use when needed. It was implied that CSR has convincing potential to boost reading-comprehension improvement among EFL students and is applicable for content-based learning as well. 
The result of the study also parralel positively with the theory of Vaughn, Klingner \& Bryant (2001) which states that CSR has been used both as part of the multicomponent approach to enhance reading outcomes and as an instructional practice designed to promote reading comprehension and content-area reading. In relation to those CSR goals, the result of this study has shown that CSR improved students' reading comprehension indicators as stated in the decree of the Minister of Education No. 4/2018. First, in the scope of texts' social function, the students were able to identify, compare, classify, conclude and analize the social function of the text in terms of its topic, purpose, background, impact, value, the role of speaker and readers, and the usage context in the text social function. Since the first strategy of CSR obliges the readers to do preview strategy which aimed to activate background knowledge, make connection between the texts' topic and prior learning, predict what might be learned and set a purpose of reading (Klingner et al, 2012). Secondly, in language feature scope, the students were to identify, compare, classify, explain, conclude, give details and analize the language feature of the text in terms of word synonym and grammatical reference as the second strategy of CSR (click \& clunk) facilitated the students to be able to guess and find the meaning of some words or parts of the text which disrupt the text comprehension. Thirdly, the students were able to identify, compare, classify, explain, conclude and provide details of the relationship among the text parts since the third and fourth strategies (get the gist \& wrap up) accomodated the students ability in determining the main idea in the section of the text they have just finished reading and identifying the most important ideas in the passages (Klingner et al, 2012).

The next reason is in supporting the students' comprehension development, CSR were also equipped with some supportive materials that help the students to comprehend the text better. In this study, some materials of CSR consisted from sample CSR lesson that outlined the procedures during CSR group discussion were used. In addition, CSR learning log which record the students ideas during discussion were also provided. In the local context, a study of CSR implementation conducted by Gani, Yusuf \& Susiani (2016) implied that the students' performance in reading test taught using CSR outperformed those taught using non-CSR approach. CSR also succeded in improving the students reading score from 67 to 88 in (Riani, 2013 ). The finding states that CSR support to enhance the students' reading skill as well as affecting the students' outcomes positively in regards to the students' social relationships and interactions in the classrooms. The similar result was found in this study. Assigning the students to work in pairs and group supports the students' gain in reading comprehension. This is parrarel with Klingner et al (1998) stating that working in groups can increase the students' self confidence as each of them can decide their own roles and participation in the discussion. CSR also enables the students to monitor students' reading comprehension by working in group (Klingner et al, 2012). This process affects positively in the students' achievement in reading.

On the other hand, in order to provide a comprehensive discussion on the effect of CSR on students' reading comprehension, this part also present some findings constrasting to the study. A study conducted by Nosratiana \& Mohammadi (2017) yielded a different result. When CSR was compared to another reading instruction, it was found out that CSR did not outperform the non-CSR strategy. Conducted in Iran with 58 homogenous EFL female subjects, it was believed that the current trend in ELT pedagogy is immensely in favor of collaborative activities among EFL learners (Nosratinia \& Zaker, 2015) which somehow reflected in CSR. On the other hand, culture is believed to play a major role in the way L2 is mastered (Zaker, 2016). Thus, there have always been concerns if collaborative activities are necessarily compatible with the ELT practice in all contexts for different cultures. Knowing that many Iranian EFL learners based on their cultural beliefs and upbringings are not really interested in collaborative activities (Amirkhiz, Bakar, Mamoudi, 2013). This finding was surely in contrast with the cultural beliefs and upbringings of the subjects in this study. The subjects of this study are Indonesian students', particularly Javanese students. Javanese is famous for its cultural beliefs and characters in working together and helping each other. Thus, the subjects did not find difficulties in collaborative work as what the subjects of the previous study might experienced. In conclusion, it was found that the result of the study about the significant effect of CSR to EFL students' reading comprehension was consistent with the majority of previous studies on CSR. In this study CSR was proven to be a more effective reading strategy than the conventional one in boosting EFL students' reading comprehension.

In the background of the study, some of the previous studies on group sizes were also presented. The previous studies show different findings since the group size was implemented in different skills and conditions. A study conducted by Morrow and Smith (1990) assigned the students in different group sizes in narrative reading. The finding revealed that the students assigned in small groups outperformed the students taught in whole class instruction. Another study conducted by Elbaum, Vaughn, Hughes, \& Moody (1999) in a reading class assigned the students with dissabilities in different group sizes indicated that assigning students in smaller group sizes affects the students' outcomes in reading. And the students pairing apparently yielded the strongest effect. Moreover, Lasito \& Storch (2013) found that pairing makes the students produce more oral language than those in small groups.

As regards to the second research question, the result of t-test to test the second hypothesis testing, implied that there was no significance difference between the students assigned in pairs and small groups of four. It means that the students assigned in pairs did not gain a better result in their reading comprehension than the students assigned in small groups of four. The evidence was shown in the disparity of mean scores between the students assigned in pairs and those assigned in small groups of four. The contrast of both groups was barely seen since the difference point was 0.01 with the favor in pairs group. 
This evidence was later confirmed from the result of T-test suggesting that there was no significant difference between the two groups tested. Therefore, it was concluded that in this study, pairs was insignificant to be a more effective group arrangement size than small group of 4 in enhancing the students learning outcomes in reading comprehension.

This present study yielded similar to a study conducted by Mayo \& Zeitler (2016) which investigated whether the learner set up in interaction in the form of pairs and small groups affected the frequency and outcome of lexical languagerelated episodes (LREs) and L2 vocabulary learning. The subjects were 30 Spanish EFL university learners working in four groups and seven pairs on the same collaborative writing task. The quantitative analysis of the data showed that there was no significant difference between the performance of pairs and groups. It was implied that the insignificant difference of performance of both pairs and small groups was linked to the characteristics of each individuals. The finding of this study is similar to a study conducted by Young (2008) investigating whether the less group number tutoring promoted a greater reading growth than those who have more number of group. It was revealed that the effect sizes did not proven to be significantly affecting the students' learning outcomes.

There are some reasons to justify the insignificance of the group size arrangement to the students' reading comprehension in this study. The first reason is that although the subjects may be familiar with each other, not all of them can be expected to collaborate the same way as the others do. Some pairs and group were found to be more collaborative than others. In many cases, it was also indicated that more numbers in groups might be helpful in solving linguistics problem. The same circumstances happens to the present study. CSR was applied in collaborative work and during the implementation of the strategy, some groups were found to be more collaborative than the other groups either in pairs or in groups of four. Another reason on why the effect of group size was insignificance in the students' reading comprehension might be from the group structure arrangement. In assigning the group, the students were distributed in group based on their ability. This made the groups belong to heterogenous group. Heterogenous composition of a group might be advantageous for each group relatively had the same speed in completing the activities provided during the lesson. Those who have higher ability might help the other members with the lower ability to speed up the task completion. Yet, a meta-analysis by Lou, Abrami \& Spence (2000) implied a slight advantage of homogenous over heterogenous grouping, though this this result depends on curriculum area, students' ability and probably task. Here, the benefits of homogenous grouping over heterogenous grouping were found greatest in reading and less in math and science.

The finding in the present study constrasted the finding of the study conducted by Elbaum et al (1999). The study was a meta-analysis study to determine effects of grouping practices on students with disabilities in grades 1-6. The study reviewes 22 intervention studies to determine the most effective grouping format among pairs, small groups (groups of 3-10 students) and multiple grouping formats (mix between pairs and small groups). The result indicated that the small groups outperformed students in whole classroom instruction. It was also revealed that the fewer number of students yielded a more effective result. The contrasting finding might be due to difference types of students' role in the activity. The previous study assigned the role of the group in tutored groups while in the present study, the students were assigned to be reponsible in certain roles like leader, click and clunk expert, get the gist expert and timer in the class activities.

The hypothesis testing for the third research question revealed that there was no interaction between teaching strategies and group arrangement sizes. It means that whatever group size is assigned to the students in implementing CSR, either pairs or small groups of 4, it does not affect the students' reading comprehension. It is parralel with the finding revealed by Vaughn, Klingner \& Bryan (2001). Different group sizes, pairs and small groups, as well as different strategies, peer-mediated and CSR, were applied in this study. All groups made significant progress both in reading comprehension and context learning. It means that both group sizes do not differ significantly regardless the reading strategy used. Further analysis on the difference of the roles of difference group sizes on each reading strategy was no need to be conducted. The absence of interaction between teaching strategies and group arrangement sizes indicates that there is no difference between the students taught using CSR assigned in pairs and small groups. Since the interaction between the reading strategies and group sizes was barely found it also means that the reading comprehension of the students taught using conventional strategy assigned in pairs does not differ from those assigned in small groups.

The result might be caused by several factors. Vaughn et al (2001) found out that the subgroups of very poor readers made unsignificant or even no gains at all in reading achievement compare to the other groups with the same strategies and group sizes. Thus, the achievement might not be affected by the group sizes, but rather on the structure of the group itself. The progress of each group should also be monitored to ensure that the students making adequate progress. It was possible that a particular students or selected students within group failed to make adequate progress. The eight-week treatment in this study was lacking in making a quick adjustment in the group arrangement since the students were set in the same group from the beginning till the end of the treatment. Besides, CSR relies on the collaboration of the group members a lot. In preview strategu, students who have some prior knowledge on certain issues or topic being discuss in the text gains more benefits than those who don't. Another strategy like click and cluck is also beneficial more for the groups whose members posses more vocabulary 
mastery than those who don't. The inability of the group members to give contribution to the collaboration work might be another factor in the absence of interaction between reading strategy and group sizes.

Associated with the theory of reading teaching for EFL students, the findings of this research contribute some positive inputs. Implementing CSR in EFL reading class support the ability of the students to gain reading comprehension with strategic reading. Once the students get familar with the strategies in CSR, they may be able to implement in in any kind of reading text. Click and clunk strategy helps the students to get used to make predictions on new vocabulary they don't know before. It enables the students to gain more reading comprehension on the new texts with the different level of vocabulary. Strategy of get the gist create a habit for the students to make some inference an d conclusions on the text they read. Moreover, CSR requires the students to work collaboratively and interact more with their peers. This was more motivating for them since some students may find that interacting with teachers is challenging. In brief, CSR give positive contribution to increase the students' comprehension in reading, communicating skill as well as force them to be more active in class. Yet, it is suggested that in applying collaborative reading, group arrangement sizes need not be put into consideration since it was assumed that it give no influencial effects to students' learning outcomes in reading comprehension. Regardless of the group size assignment, CSR was recomended to be applied in EFL students' reading class, especially in expository texts.

This research is aimed at investigating the effect of CSR on students' reading comprehension in different group sizes. All the findings and the result of the analysis are used to confirm that CSR support the improvement of students' reading comprehension in expository texts. Thus, theoritically it support the eficacy of CSR in EFL students' reading comprehension. Pedagogically, the finding of this study might imply that CSR is an effective strategy to be applied in reading class to enhance the students' reading comprehension. Since most students of senior high school struggle to gain reading comprehension, English teachers might find CSR as an alternative of reading strategy to be applied in their reading classes.

Since the students of SMAN Model Terpadu Bojonegoro struggled in reading English texts, practically the implementation of CSR might be helpful in their reading classes, especilly in expository texts. The teachers can apply the procedure of CSR in any group arrangement suitable with the characteristics of the class since group size was assumed to give no influencial effects to students' learning outcomes in reading comprehension. This quasi-experimental study conducted in a senior high school that it is impossible for the researcher to choose the most ideal schedule arrangement for the four classes as the subjects of the study. Moreover, the treatment of this study was only 8 meetings. During the implementation of CSR, it takes time to make the students get used to and familiar with the strategies in CSR. The longer period of treatment might yielded a more comprehensive findings on the effect of CSR on EFL students' reading comprehension. The more adequate length of treatment might enable the researcher to give more adjustement to the students who were indicated to gain less improvement during the treatment.

The constraints of the study was also generated from the strategies of CSR applied in the classroom. Students' limited vocabulary made it hard for them to do strategies of click and cluck and get the gist. The students' tendency and old habit of looking up the meaning of the difficult words in dictionary might find it difficult to apply the click and clunk strategy. Eventhough the study has confirmed that CSR contribute positive effect for students' reading comprehension significantly, the constraints mentioned above may hinder the students to get optimum advantages from CSR strategy.

\section{CONCLUSIONS}

Based on the result of the analysis conducted in this study, the researcher comes to several conclusions. The first conclusion is that the study suggests that the students taught using CSR achieved significantly better than those taught using conventional strategy. Hence, a conclusion can be drawn that CSR is a more effective strategy compared to the conventional strategy used in teaching reading, particularly for expository texts. Second, the finding of the study also reveals that there was no significant difference in achievement in the students assigned in pairs and in small group of 4 . Therefore, it can be concluded that there was no interaction between the strategy used in teaching reading with the group arrangement sizes assigned to the students in reading class. Since the result of the analysis fails to prove the presence of the interaction between the reading strategies used in this study and the gruop sizes assigned to the students, the last two research problems investigating the difference of the students applying certain strategy in different group arrangement sizes could be ignored. To sum up, the study implied that the use of CSR indeed had impact on the students' reading comprehension in expository text. In spite of this, the study failed to confirm the effect of CSR across the group sizes assigned to the students in reading class. In addition, this study also failed to confirm the interaction between the strategy used in teaching reading and the different group sizes arrangement.

There is a hope that this article is able to initiate a call for action for the english teaching and learning, particularly in implementing strategic reading in reading class. Apparently, more future research on the effects of CSR conducted on high school students providing a rich understanding of CSR is the only way to assure that CSR can be viewed as an effective educational tool for the EFL students in high school level. Overall, findings of this study demonstrate that EFL learners can benefit from the implementation of CSR. Certainly, a well organized group learning combined with the research-based reading strategy holds promising result on enhancing the students' reading skills. Therefore, it is suggested that the EFL reading 
teaching and learning in senior high school level includes the combination of collaborative learning and strategic reading instruction. Moreover, considering the positive effects of CSR in students' reading comprehension, English teachers are suggested to use CSR as an alternative way to teach reading. English teachers are also recomended to have adequate knowledge and understanding on the procedure of CSR, the implementation of the four strategies in CSR as well as the use of learning logs and cue cards. It is also recomended for the teachers to provide some pictures or clues to hep the students in the click \& clunk strategy. The teachers should be active in finding some attractive and up-to date materials to teach reading since it can be easily found in onlines. Any resources will also do. English materials can be from English magazines, books, English books, internet and even things or phenomena happen in our surrounding. With the trend of $21^{\text {st }}$ century learning, students are expected to be more collaborative. Thus, the teachers must emphazis the importance of strategic and collaborative learning to the students.

By evaluating the lacking and the limitations of this research, future researchers are expected to conduct a more well prepared and better research. It was suggested for the future researchers to have a longer period of CSR treatment make the students familiar to the procedure of CSR and obtain a more comprehensive findings. It was also suggested for the future researchers to conduct studies related to group arrangement sizes in another aspects of English skill but reading.

\section{REFERENCES}

Adetunji, A., \& Oladeji, B. (2007). Comparative Study of the Reading Habit of Boarding and Day Secondary School Students in Osogbo, Osun State, Nigeria. Pakistan Journal of Social Sciences, 4(1), 509-512.

Alamin, A., \& Ahmed, S. (2013). A Study of Reading Strategy Awareness among College English Major at Taif University, KSA; and Factors Affecting Reading Comprehension. Studies in Literature and Language, 7(3), 12.

Amrina, R. (2016). The Effect of Collaborative Strategic Reading (CSR) on Reading Comprehension of Students across Different Learning Styles. Unpublished thesis. Universitas Negeri Malang, Malang.

Ary, D., Jacobs, L., \& Sorensen, C. (2010). Introduction to Research in Education. Bellmont: Wardsword.

Boardman, A. G., Vaughn, S., Buckley, P., Reutebuch, C., Roberts, G., \& Klingner, J. (2016). Collaborative Strategic Reading for Students with Learning Disabilities in Upper Elementary Classrooms. Exceptional Children, 82(4), 409-427. https://doi.org/10.1177/0014402915625067

Clark, C., \& Akerman, R. (2006). Social Inclusion and Reading: An Exploration. London: National Literacy Trust. London: National Literacy Trust.

Gani, S. A., Yusuf, Y. Q., \& Susiani, R. (2016). Progressive Outcomes of Collaborative Strategic Reading to EFL Learners. Kasetsart Journal of Social Sciences, 37(3), 144-149.

Calhoon, M. B. 2005. Effects of a Peer-Mediated Phonological Skill and Reading Comprehension Program on Reading Skill Acquisition for Middle School Students with Reading Disabilities. Journal of Learning Disabilities, 5, 424-433.

Davis, B. G. (1993). Tools for Teaching. San Francisco: Jossey-Bass Inc.

Direktorat Pembinaan Sekolah Menengah Atas. (2017). Panduan Penilaian oleh Pendidik dan Satuan Pendidikan Sekolah Menengah Atas. Jakarta: Direktorat Pembinaan SMA Ditjen Pendidikan Dasar dan Menengah.

Elbaum, B., Vaughn, S., Hughes, M., Moody, S. W., \& Schumm, J. S. (2000). Grouping Practices and Reading Outcomes for Students with Dissabilities. Exceptional Children, 65(3), 399-415.

Elbaum, B., Vaughn, S., Tejero, H., Moody, W. \& Sally. (1999). Grouping Practices and Reading Outcomes for Students with Disabilities. Exceptional Children, 65, 399-415. doi: 10.1177/001440299906500309.

Elfiondri., Kasim, U., Mustafa, F., \& Putra, T. M. (2017). Reading Comprehension in the PBT TOEFL: Which Sub-Skills Deserve More Intensive Training?. TESOL International Journal, 15(1), 53-64.

Fisher, B. A. \& Ellis, D. G. (1990). Small Group Decision Making (3rd ed). New York : Mc Graw Hill

Grabe, W. (2009). Reading in Second Language: Moving from Theory to Practice. New York: Cambridge University Press.

Harmer, J. (2007). How to Teach Writing. Essex: Pearson Longman.

Ivey, G., \& Broaddus, K. (2001). "Just Plain Reading”: A Survey of What Makes Students Want to Read in Middle School Classrooms. Reading Research Quarterly, 36(4), 350-377. https://doi.org/10.1598/RRQ.36.4.2

Karabuga, F., \& Kaya, E. (2013). Collaborative Strategic Reading Practice with Adult EFL Learners: A Collaborative and Reflective Approach to Reading. Procedia-Social and Behavioral Sciences, 106, 621-630.

Khonamri, F., \& Karimabadi, M. (n.d.). Khonamri, F., \& Karimabadi, M. 2015. Collaborative Strategic Reading and Critical Reading Ability of Intermediate Iranian Learners. Theory and Practice in Language Studies, 5(7).

Kim, A. H., Clapper, A. T., Vaughn, S., \& Bremer, C. (2002). Collaborative Strategic Reading (CSR): Improving Secondary Students' Reading Comprehension Skills (NCSET Research to Practice Brief). Retrieved from http://conservancy.umn.edu/handle/11299/172990

Klingner, J. K., \& Vaughn, S. (1999). Promoting Reading Comprehension, Content Learning, and English Acquisition through Collaborative Strategic Reading (CSR). Reading Teacher, 52(7), 738-747. 
Klingner, J. K., \& Vaughn, S. (2000). The Helping Behaviors of Fifth Graders While Using Collaborative Strategic Reading During ESL Content Classes. TESOL Quarterly, 34(1), 69-98. https://doi.org/10.2307/3588097

Klingner, J., Vaughn, S., Dimino, J., Schumm, J. S., \& Bryant, D. P. (2001). From clunk to click: Collaborative Strategic Reading. Longmont: Sopris West.

Lasito, \& Storch, N. (2013). Comparing Pair and Small Group Interactio

ns on Oral Tasks. RELC Journal, 44(3), 361-375. https://doi.org/10.1177/0033688213500557

Leech, N. L., Barret, K.C., \& Morgan, G.A. (2005). SPSS for Intermediate Statistics: Use and Interpretation. London: Lawrance Erlbaum Associates Publishers.

Lou, Y., Abrami, P. C., \& Spence, J. C. (2000). Effects of Within-Class Grouping on Student Achievement: An Exploratory Model. Journal of Educational Research, 94(2), 101-112.

Mayo, M. \& Zeitler, N. (2016). Lexical Language-Related Episodes in Pair and Small Group Work. International Journal of English Studies, 17(1), 61-82.

Morrow, L. M., O’Connor, E.M., Smith, J. K. (1990). Effects of a Story Reading Program on the Literacy Development of AtRisk Kindergarten Children. Journal of Reading Behavior, 22(3), 255-275 https://doi.org/10.1080/10862969009547710

Nohenriady. (2011). Using Collaborative Strategic Reading to Improve the Eight Graders' Reading Comprehension at MTsN Sungai Pandan South Kalimantan. Graduate Program in ELT, Universitas Negeri Malang, Malang.

Nosratinia, M. \& Mohammadi, E. (2017). The Comparative Effect of Teaching Metecognitive Strategies and Collaborative Strategic Reading on EFL Learners' Reading Comprehension. International Journal of Applied Linguistics \& English Literature, 6(3).

Nosratinia, M., Zaker, A., \& Saveiy, M. (2015). Higher-Order Thinking and Individualized Learning: Metacognitive Awareness and Self-Efficacy among EFL Learners. The Iranian EFL Journal, 11(1), 189-207.

Pressley, M., El-Dinary, P., Gaskins, L., Schuder, T. L., Bergman, J., \& Almansi, A. E. (1992). Beyond Direct Explanation: Transactional Instruction of Reading Comprehension Strategies. Elementary School Journal, 92, 511-554.

Riani, D. O. (2013). Collaborative Strategic Reading Implementation to Improve Students' Reading Comprehension. English Review: Journal of English Education, 1(2), 231-239.

Rosenshine, B., \& Meister, C. (1995). Scaffolds for Teaching Higher-Order Cognitive Strategies. In A.C. Ornstein (Ed.) Teaching: Theory into Practice. Boston: Allyn \& Bacon.

Sulistyo, G. H. (2011). Reading for Meaning: Theories Teaching Strategies and Assesment. Malang: Pustaka Kaiswaran.

Sulistyo, G. H. (2013). Assessing Non-English Department Students' Mastery of Academic Content Area Reading. Jurnal Ilmu Pendidikan, 19(1), 37-49.

Vaughn, S., Klingner, J. K., Swanson, E. A., Boardman, A. G., Roberts, G., Mohammed, S. S., \& Stillman-Spisak, S. J. (2011). Efficacy of Collaborative Strategic Reading with Middle School Students. American Educational Research Journal, 48(4), 938-964. https://doi.org/10.3102/0002831211410305

Wedgeworth, R. (2004). The Literacy Challenge. IFLA Journal, 30(1), 14-18.

Wilkinson, I. A. \& Fung, I. Y. (2002). Small-Group Composition and Peer Effects. International Journal of Education Research. 37, 425-447.

Zaker, A. (2016). The Acculturation Model of Second Language Acquisition: Inspecting Weakness \& Strength. Indonesian EFL Journals, 2(2), 80-87.

Zhou, S. (2010). Comparing Receptive and Productive Academic Vocabulary Knowledge of Chinese EFL Learners. Asian Social Science, 6(10). 